\title{
Nothnagel 症候群を呈した脳幹梗塞例のリハビリテーション経験
}

\author{
田中一成*1 佐藤友治*2 山口淳*1
}

\section{Stroke Rehabilitation for Nothnagel Syndrome : A Case Report}

\author{
Kazunari TAnaka, ${ }^{* 1}$ Tomoharu Sato, ${ }^{* 2}$ Jun Yamaguchi, ${ }^{* 1}$
}

\begin{abstract}
We report a case of Nothnagel syndrome with inattention. A 69-year-old laborer was admitted to our hospital for rehabilitation therapy complaining of gait disturbance a month after the onset of brainstem infarction. He had right oculomotor palsy, ataxia on the left side and upward movement limitation of the left eye. Magnetic resonance imaging demonstrated high signal intensity in the right tegmentum of the midbrain and the medial aspect of the right thalamus on T2-weighted and diffusion weighted images. This lesion involving nuclei in the medial aspect of the right thalamus, which is considered to be closely related with the reticular activating system, might explain his inattention. And it is suggested that the low blood flow in the right basal ganglia and parietal lobe revealed by his SPECT scan, could be related with that as well. We administered rehabilitation programs for his ataxia and inattention. Because diplopia is thought to be difficult to improve, we did not attempt to treat the patient's eye movement limitation. Three months after our intervention, he was able to walk without support. However, his inattention remained. Patients with brainstem infarction are apt to have plural impairments concurrently. In such cases, it is necessary to assess the treatment priority for each impairment adequately. Evidence based guidelines for the assessment of treatment priority would aid in this endeavor and the development of such guidelines is therefore expected. (Jpn $\mathbf{J}$ Rehabil Med $2007 ; 44: 280-285)$
\end{abstract}

Key words : Nothnagel 症候群 (Nothnagel syndrome), リハビリテーション (rehabilitation), 注意障害 (inattention), 機能予後 (functional prognosis)

はじめに

Nothnagel 症候群は，1879 年に Nothnagel が四丘体 腫瘍により動眼神経麻痺と運動失調を呈した剖検例を 記載したことに因んで命名された1)。しかし，同症例 の報告は少なく，さらに多彩な障害のために難渋する と考えられるリハビリテーション（以下，リハ）やそ の帰結に関する記載はきわめて少ない。今回, 中脳梗 塞により本症候群を呈した症例を経験した。過去の報 告例とともに本症候群のリハおよびその障害帰結につ いて考察したので報告する.
症例

患 者：69 歳, 男性, 鉄筋工.

主 訴: 歩行障害.

家族歴：特記事項なし.

既往歴：55 歳時より糖尿病治療中であったがコン トロールは良好であった。病前の行動はきわめて慎重 で性格は几帳面であった。

現病歴：就業中, 意識レベルの低下を認め, 救急搬 送された，意識は直ちに改善したが，左上下肢の筋力 低下があり, 精查の結果, 脳幹部梗塞と診断された。 保存的治療後, 発症後 1 カ月で当院回復期リ 八病棟に

2006 年 11 月 21 日受付, 2007 年 3 月 15 日受理

*1 大阪医科大学リハビリテーション医学教室/ $\overline{1}$ 569-8686 大阪府高槻市大学町 2-7

Department of Rehabilitation Medicine, Osaka Medical College

*2 おおくまリハビリテーション病院/テ 661-0953 兵庫県尼崎市東園田町 4-23-1

Okuma Rehabilitation Hospital

E-mail address : reh030@poh.osaka-med.ac.jp 
入院した。

入院時所見: 血圧 $132 / 72 \mathrm{mmHg}$, 脈拍 $70 /$ 分, 整. 意識清明. 会話に支障なく, 指示理解も良好. 右眼瞼 下垂を伴った動眼神経麻痺と, 左眼上転障害を呈し (図 1), 曈孔は右 $3.0 \mathrm{~mm}$, 左 $1.5 \mathrm{~mm}$ と不同であった. 対光反射は右眼で消失. 左眼の輻輳反射は保たれてい
たが，人形の目現象は陰性. 体幹，左上下肢ともに運 動失調を認めた（表 1). 感覚異常や振戦は認めなか った。また左上下肢深部腱反射充進と, Brunnstrom recovery stage (以下 BRS) V の左片麻痺を認めた. 空 間的注意は保たれていたが，全般性注意障害を認めた (表 1). その他の高次脳機能には異常を認めなかっ

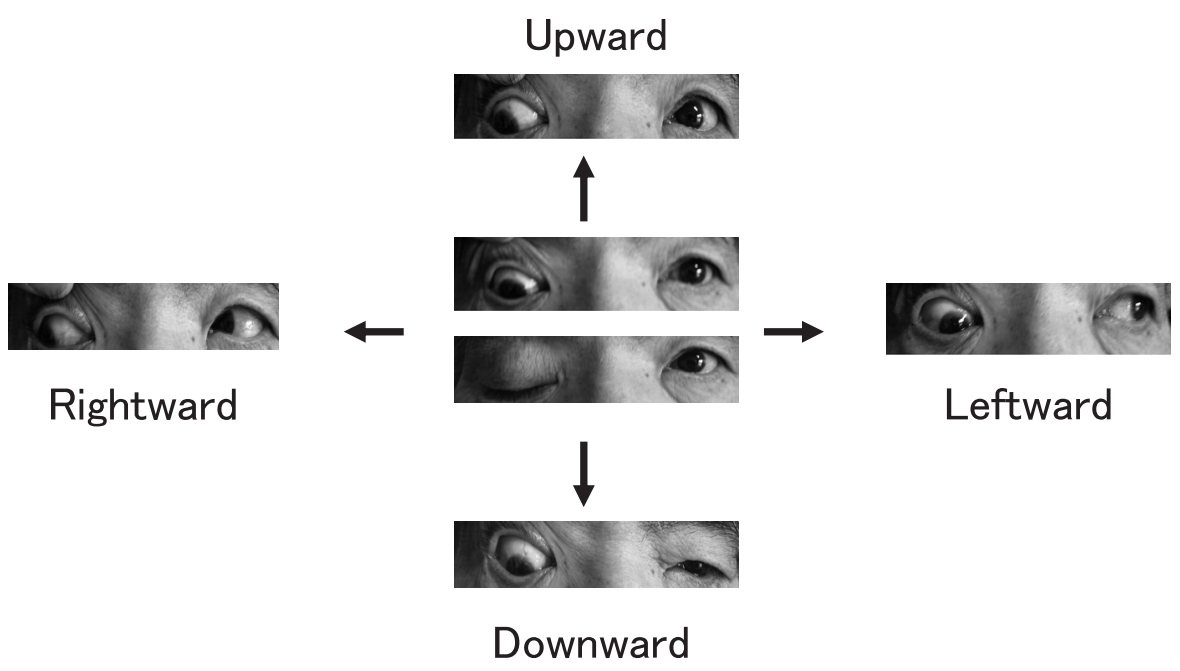

図 1 眼球運動

右眼瞼下垂を伴った動眼神経麻瘻と，左眼の上転障害を呈していた.

表 1 神経心理学的検査・他

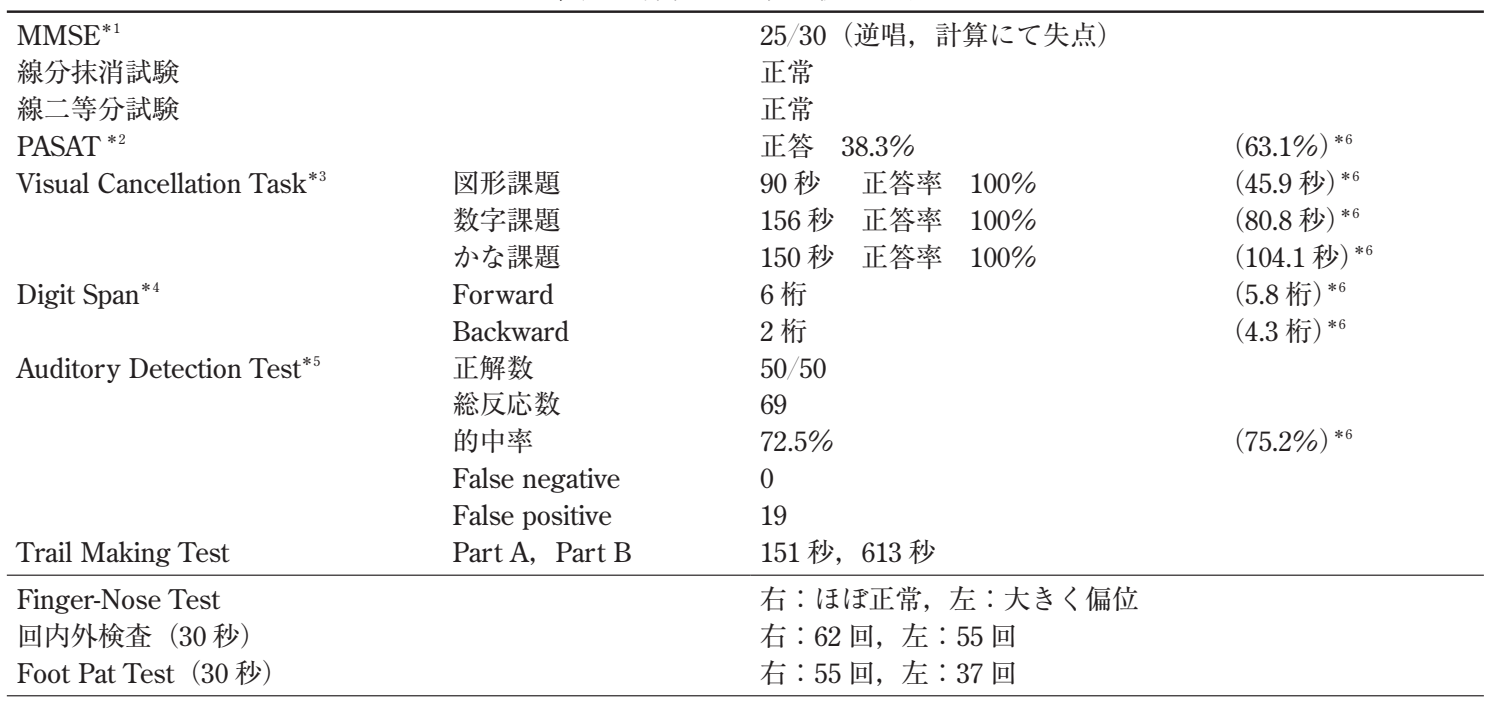

${ }^{* 1}$ Mini-mental State Examination, ${ }^{* 2}$ Paced Auditory Serial Addition Task 2 秒条件, ${ }^{* 3}$ 視覚性抹消検查, ${ }^{* 4}$ 数唱, ${ }^{* 5}$ 聴覚性 検出課題, ${ }^{* 6}$ 標準注意検查法（日本高次脳機能障害学会編）による健常 60 歳代平均值

PASAT から注意の分配, 制御性の障害が疑われ, Digit Span における Forward と Backward の乘離は制御系注意, ワー キングメモリーの障害を示唆する。眼球運動障害があり, Visual Cancellation Task, Trail Making Testの評価は難しいが, Auditory Detection Test な゙から，選択的注意は良好と考えられる. 
た。

検查所見：MRIで上丘レベルの右中脳被蓋傍正中 部から視床内側にかけた領域に梗塞像を認めた（図 $2-\mathrm{a})$. 発症後 3 カ月の SPECT $\left.{ }^{99 m} \mathrm{mc}-\mathrm{HMPAO}\right)$ では, 右側基底核および頭頂葉, また左側前頭葉, 頭頂葉と
小脳半球における集積低下を認めた（図 2-b).

経 過: 入院当初, 眼性斜頸を呈し身体正中感覚の 低下も著明であった。加えて体幹失調により，座位場 面では，左後方に崩れるも自己修正が難しく，また四 肢の失調，測定障害などにより，体幹の支持として四
T2FLAIR

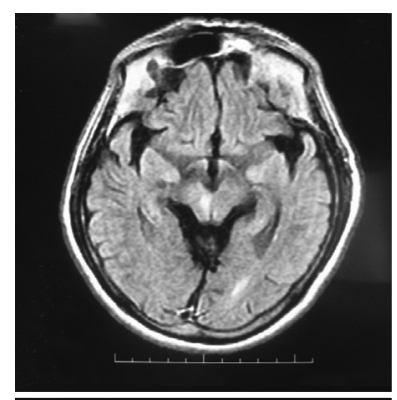

(a)

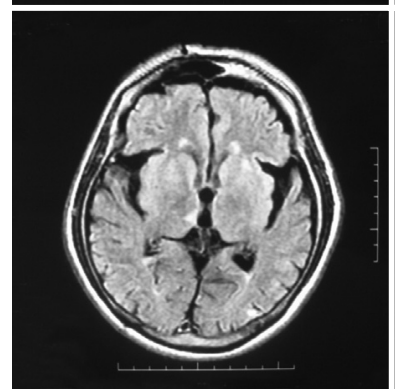

T2WI
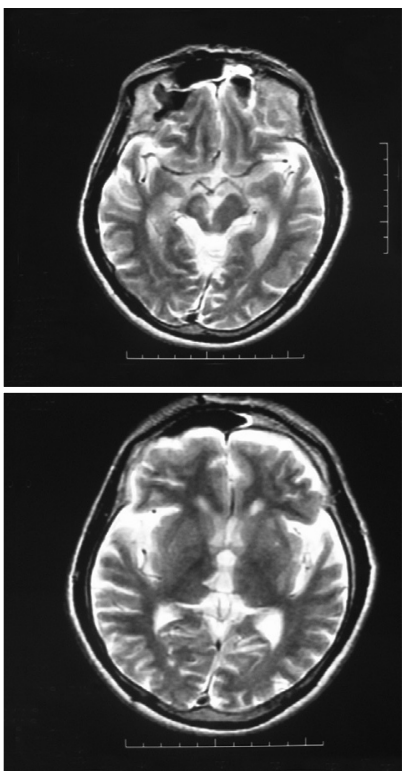

DWI
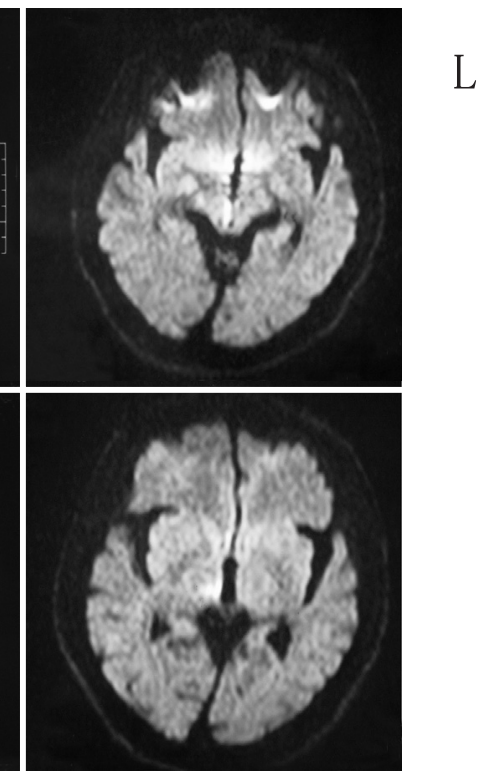

(b)

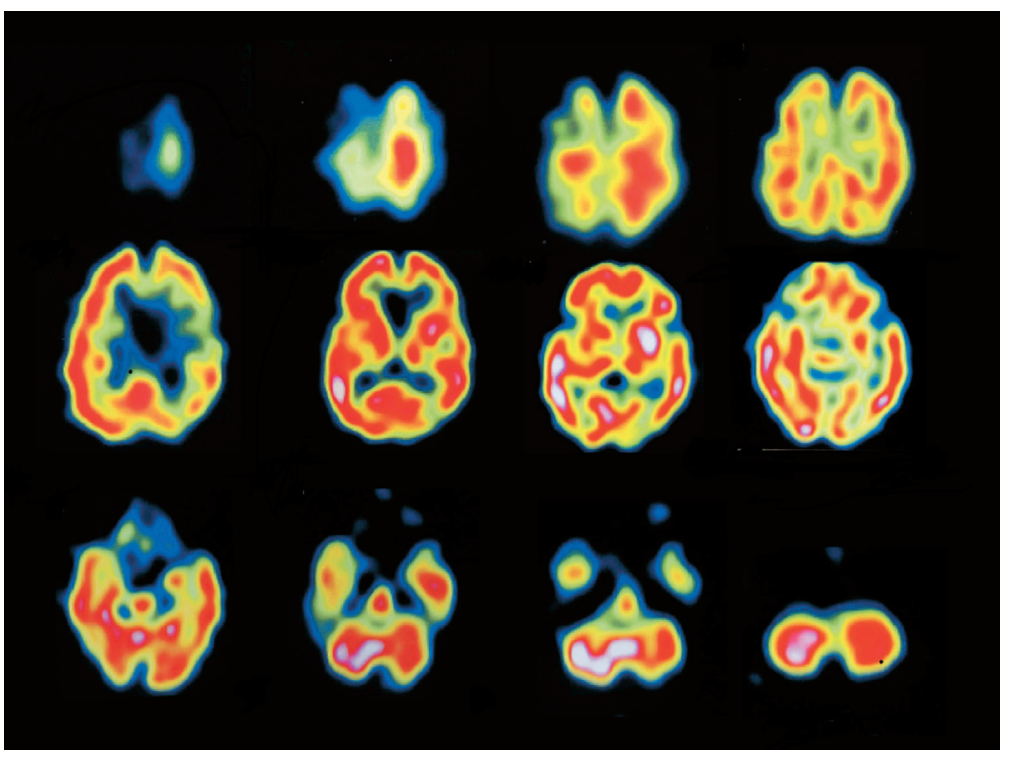

図 2

（a） MRI：上丘レベルの右中脳被蓋傍正中部から視床内側にかけた領域に梗塞を認めた（b) SPECT ${ }^{999 \mathrm{~m}} \mathrm{Tc}$ HMPAO）：右側基底核および頭頂葉，また左側前頭葉，頭頂葉と小脳半球における集積低下を認めた。 
肢を用いることもできなかったため, 座位保持は不能 な状態であった。そこで視覚障害の代償と考えられる 姿勢異常に対しては, 鏡を用いた訓練と繰り返しの声 かけによる修正を行い，失調に対しては，上肢に $300 \mathrm{~g}$, 下肢に $600 \mathrm{~g}$ の重錘を装着して日常生活動作

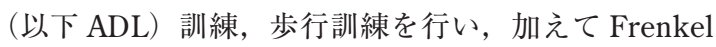
体操を指導した。

治療開始後 1 力月で姿勢異常, 身体正中感覚に改善 を認め, 座位・静止立位保持は安定したが, 体幹失調 によると考えられる後方へのバランスの崩れにより歩 行障害は残存した. しかし失調は 2 力月後頃より徐々 に, 特に体幹で軽減し, 伝い歩きは監視レベルで, 訓 練室内歩行は介助レベルで可能となった。 また 3 カ月 後には左上下肢の失調も軽減し, 左下肢の接地が円滑 になり, 屋内歩行も監視レベルで可能となった。しか し片麻痺は BRS Vのまま変化を認めず, 特に上肢は 巧緻性障害のために補助手レベルにとどまった。また 眼球運動障害も改善せず残存した。

注意障害による問題は, 便座を確認せずに座ったり, 不安定な体勢で立ち上がり転倒するなど「安全確認の ない性急な動作開始」として現れた.これらの危険行 動に対して, 注意障害が阻害因子となっている $\mathrm{ADL}$ や生活関連動作を抽出し, 動作手順を統一, 口頭で繰 り返し指導・訓練することにより汎化させることに努 めた. しかし， 3 力月間の入院期間中には著明な改善 はなく, あらゆる日常生活場面での危険が残存した。 そのため, 退院にあたっては患者・家族とともに退院 前訪問指導を実施し, 家屋環境などを確認して住宅改 修の助言を行い, 家庭内での介助・移動方法, 屋内外 での車椅子使用法を指導した。 それらに不安がなくな り, また介護保険等による社会サービスがすべて整っ た時点で自宅へ退院することが可能となった。機能的 自立評価度 (FIM) は入院時 61 点, 退院時 75 点であ った。

\section{考察}

本症例は一側の動眼神経麻痺, 対側の運動失調に加 え, 対側眼球の上転障害を呈していたことから Nothnagel 症候群と診断した ${ }^{2)}$. 過去, 本症候群の報告は 涉猟しえた範囲で 16 症例あったが, うちリハやその 帰結について記載のあるものはきわめて少なかった (表 2). しかし, リ八科診療において障害の自然経過 を把握し，予後を予測することは，リハプログラムを
作成するうえでも，きわめて重要であると考える.

眼球運動障害の帰結に関しては, 過去に 8 例の記載 があり，その内訳は改善を全く認めなかったものが 2 例, 改善を認めたが残存したものが 6 例, 軽快したも のが 2 例であった。しかし，いずれにもリ八治療の介 入例は存在しなかった. 近年, 眼球運動障害の治療と して回転刺激などを用いた治療やプリズム眼鏡によっ て単一視野領域を得る治療などが行われることがあ る.しかし本症候群は眼瞼下垂を伴う両側性眼球運動 障害であることから単一視野を再獲得することは難し く, また過去の報告からも改善はそしいと判断できる. そのため，とくに回復期リ八病棟のように入院期間が 限られた状況においては, 眼球運動の改善よりもまず, 在宅復帰のために, ADLにおける安全性向上を優先 するべきであると考える. 本症例でも眼球運動障害に 対しては個別の機能訓練的なアプローチは行わず，片 眼遮断下で訓練を行った。仮に上述の治療法を併用し 眼球運動の改善が認められても, 眼瞼下垂があり, ま た注意障害が伴った本症例の日常生活上の問題は残存 したと考えられるが, 推測の域は出ない.

過去の報告で運動失調の帰結に言及していたのは 6 症例であった. 改善なしが1例, 改善したが残存した ものが 3 例, そして軽快したものが 2 例の脳出血例で あった。一方, 片麻痺の報告は 5 例あり, 州結記載の ない 1 例を除き, 軽快と改善が 2 例ずつ存在した. 本 症例では片麻痺には変化を認めなかったものの, 重錘 負荷法によって失調の軽減を認め, 歩行は自立した。 本症例の片麻痺は BRS Vで, また過去の報告におい てもその程度は比較的軽度であり, 歩行能力の予後を 決定するのは, 片麻痺よりも残存する運動失調による と考えられた.リハプログラムを作成する上で, 初期 より十分に運動失調の評価がなされるべきであろう.

本症例には全般性注意障害が存在した. 眼球運動障 害や運動失調が前面に出るため, 注意障害について十 分に評価されていなかった可能性もあるが, 過去に注 意障害の報告はなかった。視床内側核は意識, 注意, 記憶などに深く関わるとされ ${ }^{3)}$, 両側視床傍正中部梗 塞例の SPECT において前頭葉の血流低下 ${ }^{4)}$ や前頭葉 から側頭葉にかけての斑状集積低下 ${ }^{5}$ )などが報告され ている. 本症例の SPECT においても右側基底核およ び頭頂葉，また反対側大脳皮質にも広範囲な集積低下 を認めた. 大脳皮質連合野への投射線維障害の存在も 注意障害発生に関与している可能性を示唆すると考え 
田中一成. 他

表 2 Nothnagel 症候群の報告例

\begin{tabular}{|c|c|c|c|c|c|}
\hline 報告例 & 年齢 & 性別 & 原因 & 眼球運動以外の神経症候の帰結 & $\begin{array}{c}\text { 眼球運動障害 } \\
\text { の帰結 }\end{array}$ \\
\hline Nothnagel $(1879)^{1)}$ & 20 歳 & 男性 & 肉腫 & & \\
\hline 山根ら $(1970)^{7)}$ & 65 歳 & 男性 & 脳梗塞 & 失語（D)，記銘力障害（D） & (D) \\
\hline 本宮ら $(1974)^{8)}$ & 53 歳 & 男性 & (D) & 両側の運動失調（D） & (D) \\
\hline Derakhshan $(1980)^{9)}$ & 50 歳 & 男性 & 脳梗塞 & $\begin{array}{l}\text { 寡動 }(\mathrm{D}) \text {, 記銘力障害 }(\mathrm{D}) \text {, 病変側の小脳症状 }(\mathrm{D}) \text {, } \\
\text { 構音障害 }(\mathrm{D})\end{array}$ & (D) \\
\hline 森若ら (1981) $)^{10)}$ & 47 歳 & 男性 & 脳出血 & 対側の片麻痺（A)，対側の運動失調（D） & (D) \\
\hline 小松崎ら $(1984)^{11)}$ & 22 歳 & 女性 & 脳出血. & $\begin{array}{l}\text { 対側の片麻疩（B)，対側の運動失調 }(\mathrm{B}) \text {, 対側の } \\
\text { 顔面と上肢のしびれ感 }(\mathrm{B})\end{array}$ & (A) \\
\hline 片見ら $(1984)^{12)}$ & 44 歳 & 女性 & 脳出血. & $\begin{array}{l}\text { 対側の小脳失調 (D), 構音障害 }(\mathrm{A}) \text {, 病変側の顔 } \\
\text { 面神経麻痺 }(\mathrm{D})\end{array}$ & (C) \\
\hline 日野ら $(1985)^{2)}$ & 45 歳 & 女性 & 脳出血. & 対側の運動失調（A） & (A) \\
\hline 椎野ら $(1986)^{13)}$ & 55 歳 & 男性 & 脳出血. & 見当識障害（A)，対側の運動失調（B） & (B) \\
\hline 大沼ら $(1989)^{14)}$ & 55 歳 & 女性 & 脳梗塞 & 対側の片麻痺（D)，対側の上肢運動失調（D） & (D) \\
\hline 平山ら $(1993)^{15)}$ & 58 歳 & 女性 & 脳梗塞 & $\begin{array}{l}\text { 意識障害 }(\mathrm{A}) \text {, 対側の片麻痺 }(\mathrm{A}) \text {, 対側の温痛覚 } \\
\text { 障害 }(\mathrm{A}) \text {, 四肢連動失調 }(\mathrm{B} / \mathrm{C} ?)\end{array}$ & (B) \\
\hline 望月ら $(1993)^{16)}$ & 67 歳 & 女性 & 脳梗塞 & $\begin{array}{l}\text { 見当識障害 (B?), 幻視 (B?), 両側運動失調 }(\mathrm{C}) \text {, } \\
\text { 構音障害 (D) }\end{array}$ & $(\mathrm{A} / \mathrm{B}$ ? $)$ \\
\hline 相澤ら $(1996)^{17)}$ & 72 歳 & 女性 & 脳梗塞 & 体幹の運動失調（B） & (B) \\
\hline 藤本ら $(1998)^{18)}$ & 66 歳 & 女性 & 脳梗塞 & 対側の運動失調（A） & (B) \\
\hline 宮田ら (1999) ${ }^{19)}$ & 68 歳 & 男性 & 脳梗塞 & $\begin{array}{l}\text { 一過性不随意運動 (A), 両側下肢振動覚の低下 (D), } \\
\text { 対側の運動失調 (D) }\end{array}$ & (B) \\
\hline 澤田ら $(2002)^{20)}$ & 68 歳 & 女性 & 脳梗塞 & 体幹および四肢運動失調（D） & (D) \\
\hline 筆者ら（2006） & 69 歳 & 男性 & 脳梗塞 & $\begin{array}{l}\text { 対側の片麻痺 }(\mathrm{B}) \text {, 対側の上下肢・体幹運動失調 } \\
(\mathrm{B}) \text {, 注意障害 }(\mathrm{B})\end{array}$ & (C) \\
\hline
\end{tabular}

$\mathrm{A}$ : 軽快, B : 改善あるも残存, $\mathrm{C}$ ：改善認めず残存, $\mathrm{D}$ ：記載なし

ている.

一般的に注意障害に対する確立されたリハ治療法は いまだ存在しないのが現状であるが, Sohlberg らは 認知機能に対する手法として，認知機能全般を非特異 的に刺激する general stimulating approach, 生活適応 の拡大をはかる functional adaptation approach, そし て認知障害の特異的な改善を目的とした process specific approach を挙げている6). 今回われわれは，この うち functional adaptation approach を採用したが, 治 療効果は十分ではなく，機能訓練と並行して行った家 族への指導・教育, 環境整備や社会サービス活用への 助言などといった間接的アプローチが，在宅復帰にあ たりきわめて重要であった.

以上, 本症例を含め Nothnagel 症候群の impairment レベルの障害予後は不良であった。また障害が 重複し複雑化することの多い本症候群のリハ科診療を すすめる際には，それぞれの障害に対する治療優先順 位を適切に判断する必要性を感じた。昨今 EBM に基 づいた治療が重要視される中で, 個々の障害に対する 治療方法論のみならず, 対象障害の治療優先順位の標
準化が望まれる.

本論文の要旨は, 第 43 回日本リハビリテーション医学 会学術集会（2006 年 6 月, 東京）において発表した.

\section{文献}

1) Nothnagel H : Corpora quadrigemina. in Gehirnkrankheiten, Eine Klinische Studie. Berlin Verlag von August Hirschwald 2, 1879 ; pp 204-208

2）日野英忠, 瀬川謙一, 古橋紀久, 神田直, 田崎義昭 : Nothnagel 症候群を呈した中脳出血の一例. 神経内科 ; $198523: 350-354$

3）佐藤正之, 葛原茂樹 : 視床性痴呆. 神経内科 2004 60 : 28-32

4) Bogousslavsky J, Regli F, Delaloye B, Delaloye-Bischof A, Assal G, Uske A : Loss of Psychic self-activation with bithalamic infarction. Neurobehavioural, CT, MRI and SPECT correlates. Acta Neurol Scand $1991 ; 83: 309-316$

5）織田雅也, 宇高不可思, 亀山正邦 : 両側視床傍正中部梗 塞症候群. 神経内科 $2004 ; 60: 10-15$

6) Sohlberg MM, Mateer CA : Effectiveness of an attentiontraining program. J Clin Exp Neuropsychol 1987 ; 9 : 117-130

7）山根至二 : Parinaud 症候群, 左 MLF 症候群を伴った赤 核症候群の 1 例. 臨床神経 $1970 ; 10: 518$ (抄) 
8）本宮峯生, 北岡憲一, 中川 翼, 伊藤輝史, 田代邦雄 : Claude's syndrome の 1 例. 臨床神経 $1974 ; 14: 184$ (抄)

9) Derakhshan I, Sabouri-Deylami M, Kaufman B : Bilateral Nothnagel syndrome. Stroke $1980 ; 11: 177-179$

10）森若文雄, 田代邦雄, 下山三夫, 柏葉 武 : Claude's syndrome の 1 例一その CT 像と Parinaud 症候群の合併に ついて一. 神経内科 $1981 ; \mathbf{1 5}: 76-78$

11）小松崎聡, 永野 功, 足立喬子, 岡山健次, 小久江浅二, 横田 修: 中脳出血で Nothnagel 症候群を呈した 1 症 例. 埼玉医師会 $1984 ; 19: 554-555$

12）片見睦夫, 石井久子, 石川 哲 : 中脳病変 (Nothnagel 症候群）でみられた upbeat nystagmus. 眼科臨床医報 $1984 ; 78: 672-679$

13）椎野顕彦, 市川正春, 松田昌之, 半田譲二 : Nothnagel 症 候群を呈した中脳出血. Arch Jpn Chir 1986；55： 789-795

14）大沼 寛, 鯨井 隆, 栗田啓司, 加藤丈夫, 片桐 忠, 佐々木英夫 : Nothnagel 症候群の 1 例. 臨床神経 1989 ; $29: 1318$ (抄)

15）平山恵三, 榊原隆次, 朝比奈真由美, 本間甲一, 篠遠 仁 :
中脳梗塞における被蓋傍正中背側症候群一Collier 症候 群と Nothnagel 症候群の再検討一. 臨床神経 $1993 ; 33$ : 733-739

16）望月葉子, 小町裕志, 亀谷 寛, 岸田修二, 矢野雄三 : Nothnagel 症候群を主症状とした脳梗塞の 1 例. 脳卒中 $1993 ; 15: 45-50$

17）相澤仁志, 森田一豊, 山口修二, 佐々木信博, 飛世克之, 牧田圭弘: Nothnagel 症候群の 1 例. 臨床神経 $1996 ; 36$ : 889-891 (抄)

18）藤本陽子, 磯崎英治, 吉田 寛, 林田哲郎, 平井俊策 : 一側動眼神経麻痺と対側の眼球上転障害ならびに運動 失調を呈した中脳梗塞の一例. 神経内科 $1998 ; 48: 179-$ 183

19）宮田榮三, 山本纊子, 重光利朗, 堀口正之 : Nothnagel 症 候群を主症状に多彩な眼球運動障害を呈した中脳梗塞 の一例. 神経眼科 $1999 ; \mathbf{1 6}: 69-74$

20）澤田 潤, 榎本 雪, 榎本博之, 木村 隆, 橋本和季, 箭 原 修, 相澤和季, 菊地健次郎: Nothnagel 症候群と考 えられた一例. 臨床神経 $2002 ; 42: 68$ (抄) 